\title{
Occurrence of a Citrus Canker Strain With Limited Host Specificity in South Texas
}

\begin{abstract}
John V. da Graça, Madhurababu Kunta, ${ }^{\dagger}$ Jong-Won Park, and Marissa Gonzalez, Texas A\&M University-Kingsville Citrus Center, Weslaco, TX 78599; Gem Santillana and Vessela Mavrodieva, CPHST Beltsville Laboratory, USDA APHIS PPQ, Beltsville, MD 20705; David W. Bartels and Bacilio Salas, USDA APHIS PPQ CPHST, Mission Laboratory, Edinburg, TX 78541; Maurice N. Duffel, USDA APHIS PPQ FO, Multi Pest Survey, Edinburg, TX 78541; and Jon Dale, Texas Citrus Pest \& Disease Management Corporation Mission, TX 78572
\end{abstract}

Accepted for publication 15 September 2017.

\section{Abstract}

In October 2015, a Mexican lime exhibiting citrus canker symptoms was found by the USDA APHIS PPQ in a residential property in Rancho Viejo, Cameron County, Texas. Real-time PCR analysis detected the presence of Xanthomonas citri subsp. citri; USDA APHIS PPQ in Beltsville, MD confirmed this diagnosis. A delimiting survey was initiated and suspect leaf samples were collected and sent to the PPQ Beltsville lab for analysis. By October 2017, leaf samples from 197 trees were confirmed positive for citrus canker, all within a 5-mile radius; in addition, a further 59 symptomatic trees were found and all 256 infected trees (254 Mexican lime, one makrut lime, and one Ponderosa lemon) were removed. Survey data collected on stem lesions suggested the oldest lesions to be between 4 to 6 years old. A host-range study using 12 citrus varieties, including the major commercial varieties grown in Texas, were inoculated with crude leaf extracts from symptomatic leaves by leaf infiltration method. Mexican limes and alemow were the only citrus plants that developed definitive canker lesions. A combination of host range, serological, and molecular tests suggested that this isolate was different from the typical Asiatic strain and more similar to $X$. citri subsp. citri $\mathrm{A}^{\mathrm{W}}$ which was only previously reported from Florida on Mexican lime and alemow.
Citrus canker is a highly infectious and potentially destructive disease of citrus (Gottwald et al. 2002a). Endemic to Asia, it has been introduced to citrus-growing areas in several countries. The disease was introduced into the Gulf Coast states of the United States from Japan in the early 1900s (Stevens 1914). Following eradication programs in Florida, Texas, Louisiana, Mississippi, and South Carolina, the disease was eradicated by the 1940s (Dopson 1964). However, citrus canker re-emerged in Florida in 1986 and was targeted for eradication (Stall and Civerolo 1991). In 1995, it reappeared. Citrus canker is currently endemic in the state of Florida (Irey et al. 2006). In Louisiana, citrus canker occurred again in 2013 when it was detected in ornamental citrus in a New Orleans city park (Singh et al. 2014). In Texas, the last reported case of citrus canker after the eradication campaign was in Corpus Christi in 1943 (Dopson 1964). Hosts reported with canker symptoms included trifoliate orange, sweet orange, satsumas, lemons, and pumelo, or grapefruit (Berger 1914), suggesting that the Asiatic A strain was responsible. Surveys in the commercial production areas of both the Lower Rio Grande Valley (LRGV) of south Texas and the Upper Gulf Coast have been conducted since 1999 following its re-emergence in Florida (Skaria and da Graça 2012).

Citrus canker is caused by the bacterium Xanthomonas citri, which consists of different pathovars and strains as reviewed by Gottwald et al. (2002a). The Asiatic form (Cancrosis A), designated as X. citri subsp. citri (syn. $X$. axonopodis pv. citri), is the most widespread and severe form, affecting most citrus species. The B form is caused by a related pathovar, $X$. axonopodis pv. aurantiifolia, affecting lemons

†Corresponding author: Madhurababu Kunta; E-mail: madhura.kunta@tamuk.edu

(C) 2017 The American Phytopathological Society and a few other species in some South American countries, while Cancrosis $\mathrm{C}$ caused by a variant of this pathovar appears to be limited to Mexican lime (Citrus aurantiifolia) and sour orange (C. aurantium) in Brazil. Isolates from India, Iran, the Arabian peninsula (Verniere et al. 1998), and more recently Ethiopia (Derso and Sijam 2007) affecting Mexican lime are termed A*. These isolates are serologically distinct from cancrosis A. In Florida, a variant that infected only Mexican lime and alemow (C. macrophylla) in the field, $\mathrm{A}^{\mathrm{w}}$, has been reported (Sun et al. 2004).

In October 2015, citrus canker leaf, twig, and fruit lesions (Fig. 1) were observed on a Mexican lime tree growing in a residential property in Rancho Viejo, TX. Leaf samples were submitted to the diagnostic lab at the TAMUK Citrus Center in Weslaco, TX, for analysis. The results were positive for $X$. citri subsp. citri, and were shortly thereafter confirmed by the USDA APHIS PPQ CPHST lab in Beltsville, MD. This paper reports on the identification of the strain associated with citrus canker found and the results of the delimiting survey conducted in the surrounding area.

\section{Sample Collection, Diagnostic Methods, and Removal of Infected Trees}

Sample collection and pathogen identification. USDA-APHISPPQ surveyors visit residential sites and citrus groves across the LRGV as part of an ongoing citrus disease survey. In October 2015, a Mexican lime (C. aurantiifolia) leaf sample with canker symptoms was collected in Rancho Viejo, Cameron County, TX. Tissue sections containing citrus canker lesions were excised, placed into sterile distilled $\mathrm{H}_{2} \mathrm{O}$, and boiled for $10 \mathrm{~min}$. Samples were tested for citrus canker using a universal real-time PCR assay, according to the USDA-APHIS-PPQ work instruction (Mavrodieva et al. 2004). Conventional PCR was performed with multiple primer pairs: (i) 


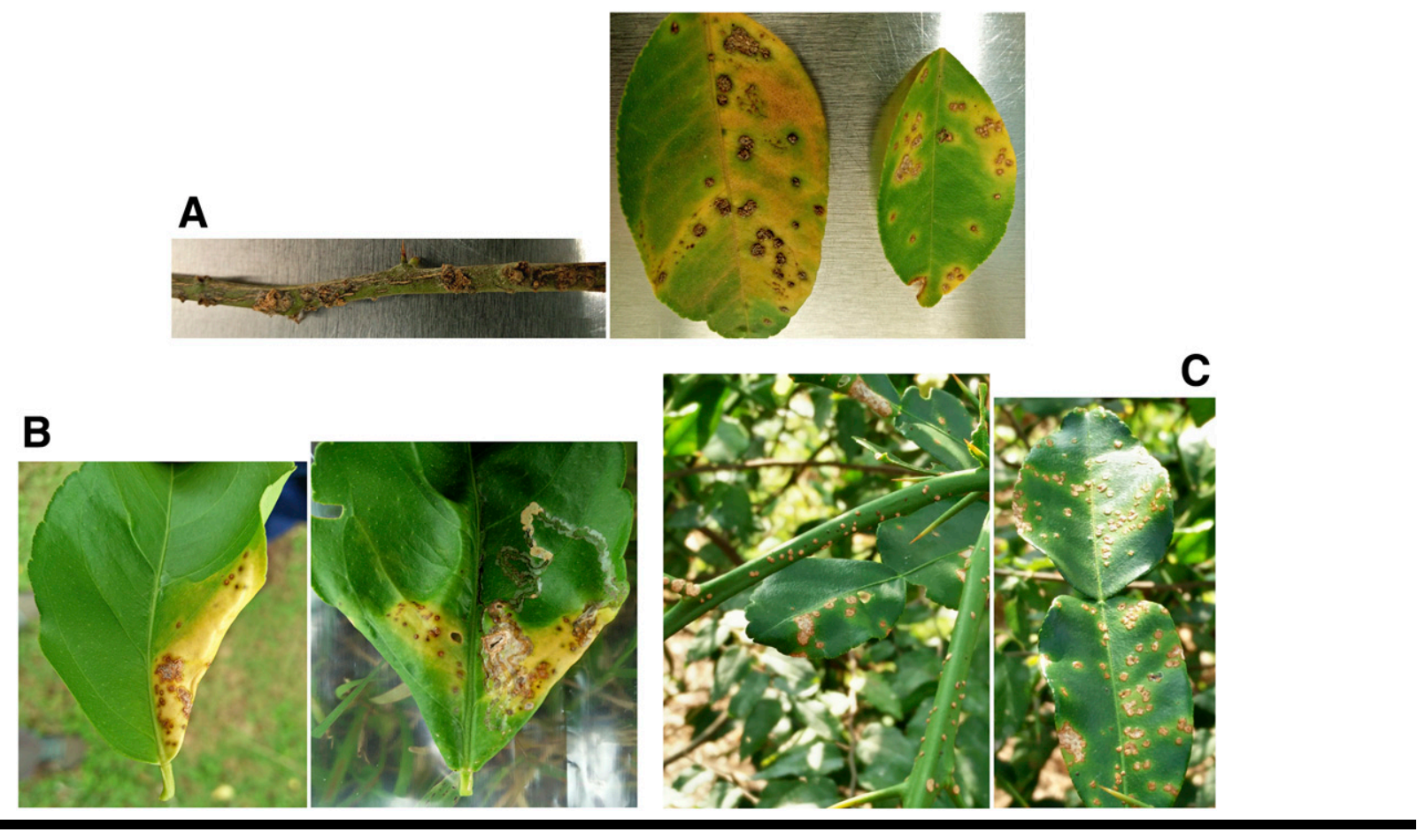

FIGURE 1

Different citrus varieties in Rancho Viejo, TX, showing citrus canker symptoms: (A) Mexican lime; (B) Ponderosa lemon with citrus leaf miner damage; and (C) Makrut lime.

Xac01/Xac02 (Coletta-Filho et al. 2006); (ii) primers described by Hartung et al. (1993); and (iii) J-pth1/J-pth2 primers (Cubero and Graham 2002). PCR with Xac01/Xac02 primer set was conducted in $25 \mu \mathrm{l}$ total volume containing $2 \mathrm{mM} \mathrm{MgCl} 2,0.1 \mathrm{mM}$ dNTPs, $2.5 \mu \mathrm{M}$ of each forward and reverse primer, $2 \mu \mathrm{l}$ template and $1.25 \mathrm{U}$ TaKaRa Ex Taq DNA polymerase (Clontech, Mountain View, CA). PCR with $J$-pthl/J-pth2 primer set was performed in $25 \mu \mathrm{l}$ sample volume containing $3 \mathrm{mM} \mathrm{MgCl}_{2}, 0.2 \mathrm{mM}$ dNTPs, $5 \mu \mathrm{M}$ of each forward and reverse primer, $2 \mu \mathrm{l}$ template, and 1.25 U TaKaRa Ex Taq DNA polymerase. The Xac01/Xac02 PCR mixtures were incubated for $3 \mathrm{~min}$ at $94^{\circ} \mathrm{C}$, followed by 36 cycles of denaturation at $94^{\circ} \mathrm{C}$ for $45 \mathrm{~s}$, annealing for $45 \mathrm{~s}$ at $60^{\circ} \mathrm{C}$, and elongation at $72^{\circ} \mathrm{C}$ for $45 \mathrm{~s}$, followed by a final 5 -min extension at $72^{\circ} \mathrm{C}$. The $J$-pthl/J-pth2 PCR mixtures were incubated for $5 \mathrm{~min}$ at $95^{\circ} \mathrm{C}$, followed by 40 cycles of denaturation at $93^{\circ} \mathrm{C}$ for $30 \mathrm{~s}$, annealing for $30 \mathrm{~s}$ at $58^{\circ} \mathrm{C}$, and elongation at $72^{\circ} \mathrm{C}$ for $45 \mathrm{~s}$, followed by a final 10 -min extension at $72^{\circ} \mathrm{C}$. PCR results were visualized by electrophoresis in $1.5 \%$ agarose. The PCR amplicons generated by $J$-pth $1 / J$-pth 2 primers were cloned into TOPO TA Cloning vector (ThermoFisher Scientific, Waltham, MA) and sequences at a commercial facility (GENEWIZ, South Plainfield, NJ). Additionally, canker lesions ground in SEB1 sample extraction buffer were tested according to Agdia (Agdia Inc., Elkhart, IN) protocol for the presence of $X$. citri subsp. citri using Xac ImmunoStrip (Agdia). The crude DNA extracts and additional leaf samples were sent to the USDA-APHIS-PPQ-CPHST laboratory in Beltsville, MD, for confirmation.

Pathogenicity assays. Twelve different citrus varieties (Table 1) were selected for pathogenicity tests. Four potted plants per citrus species were taken to the site where first found canker affected citrus trees are located, and inoculated (four inoculation sites per leaf, four leaves per citrus plant) by the leaf-infiltration method (Francis et al. 2010) using inoculum obtained by grinding leaf lesions in saline phosphate buffer (PBS; $40 \mathrm{mM} \mathrm{Na}_{2} \mathrm{HPO}_{4}+25 \mathrm{mM} \mathrm{KH}_{2} \mathrm{PO}_{4}$ ). After inoculation, leaves were covered with plastic bags to maintain high humidity levels. After $24 \mathrm{~h}$, the bags were removed and weekly observations were made on the leaves for symptom development for 3 weeks. For $C$. macrophylla, all leaves on the plant were inoculated, since only one potted plant was available for the study. The lesion tissue was collected 21 days postinoculation (dpi), washed, and DNA was extracted. PCR was performed using Xac01/Xac02 to determine the presence of $X$. citri subsp. citri.

Bacterial isolation. Three pieces (approximately $3 \times 3 \mathrm{~mm}$ each) of watersoaked areas around necrotic lesions in samples testing positive for citrus canker by real-time PCR were excised using a razor blade and placed in 1.7-ml tubes with $200 \mu \mathrm{l}$ of molecular-grade water. Tubes were incubated at room temperature with shaking $(300 \mathrm{rpm})$ for $10 \mathrm{~min}$. Samples were then diluted 1:10 in water and both diluted and undiluted samples were streaked onto nutrient agar (NA) and incubated at $30^{\circ} \mathrm{C}$ for 2 days. Resulting individual colonies from each sample were screened by a real-time PCR (Mavrodieva et al. 2004) by suspending the colony in $50 \mu \mathrm{l}$ of molecular-grade water. Bacterial suspensions were vortexed and then incubated in a boiling water bath for $10 \mathrm{~min}$. Samples were snap-chilled in ice for $5 \mathrm{~min}$ and then centrifuged at 10,000 rpm for $5 \mathrm{~min}$. Two microliters were used as template for real-time PCR using VM3/VM4 primers and VM11 probe. Colonies that were positive for the $p t h A$ gene were restreaked on NA multiple times to obtain individual colonies and screened for the $p t h A$ gene to ensure purity. Because NA is not a selective medium and will allow non- $X$. citri subsp. citri bacteria to grow, isolation was repeated using NA supplemented with cephalexin $(40 \mathrm{mg} / \mathrm{liter})$ and kasugamycin (20 mg/liter) (Pruvost et al. 2005) for samples where no colonies were positive in the initial pthA screening. Resulting 24-h-old colonies were further screened for the $p t h A$ gene and purified as described. Glycerol stocks were prepared using equal volumes of culture grown overnight in liquid medium and 50\% sterile glycerol, and stored in cryovials at $-80^{\circ} \mathrm{C}$. 
Estimating the age of infection. The infection process of citrus canker on perennial citrus trees is well defined and occurs only on plant tissues of a specific, young developmental stage. With this understanding, the approximated age of canker infection on citrus trees can be estimated (Gottwald et al. 1992, 1997, 2002a, b; Graham et al. 2004). In order to determine the approximate age and epicenter of the canker infection in South Texas, additional data were collected on most of the canker-positive trees within the quarantine area. From 2 November through 3 December 2016, 59 properties with citrus canker-positive Mexican or makrut lime trees were surveyed again for twig and stem lesions. All citrus trees on the properties were examined and data was recorded documenting tree variety, height, canopy diameter, trunk diameter $15.2 \mathrm{~cm}$ above the soil line, and location and severity of canker lesions within the tree. If stem lesions were found, branch diameter and approximate number of flushing cycles at the lesion were recorded.

Delimiting survey and tree removal. Following the confirmation of the first infected tree, USDA-APHIS-PPQ initiated a delimiting survey of 1 mile around the positive site. Additional positive tree finds resulted in new 1-mile delimiting surveys. Federal and state quarantines were declared in the area. Once a tree was confirmed positive, the property owner was notified and permission requested to remove the tree; if permission was not obtained, the Texas Department of Agriculture issued an Emergency Action Notice to facilitate removal. Tree removal was conducted by the Texas Citrus Pest \& Disease Management Corporation following strict decontamination, containment, and disposal procedures. The trees were cut down to ground level, and all parts were placed in contractor-grade trash bags; larger sections were processed through a wood chipper and collected in trash bags. The bags were buried in a landfill site. The tree stumps were treated with a registered herbicide. After removal at each site, all clothing and hands were treated with an approved soap, and all vehicle and tool surfaces were decontaminated with a bleach solution. Surveys will continue for two years after the last declared positive find before quarantines will be lifted.
Evidence of Xanthomonas citri subsp. citri in Sampled Citrus Trees, Survey, and Tree Removal

Pathogen identification. The Mexican lime leaf and twig samples submitted to the diagnostic laboratory at the TAMUK Citrus Center in Weslaco, TX, showed typical citrus canker symptoms (Fig. 1). The pustules on the leaves were raised, corky, and crateriform with water-soaked margins around the necrotic tissue and yellow halos surrounding the lesions. The pustules on stems were raised, corky, and crateriform, and brownish. Further examination of makrut lime (C. hystrix) leaves and stems showed heavy infection with typical canker lesions all over the tree while in Ponderosa lemon $(C$. limon $\times C$. medica) lesions were confined to areas of leaf miner (Phyllocnistis citrella, Lepidoptera: Phyllocnistinae) damage (Fig. 1). The real-time PCR assay with lesions (three per leaf) collected from three different leaf samples yielded threshold cycle $(\mathrm{Ct})$ values of

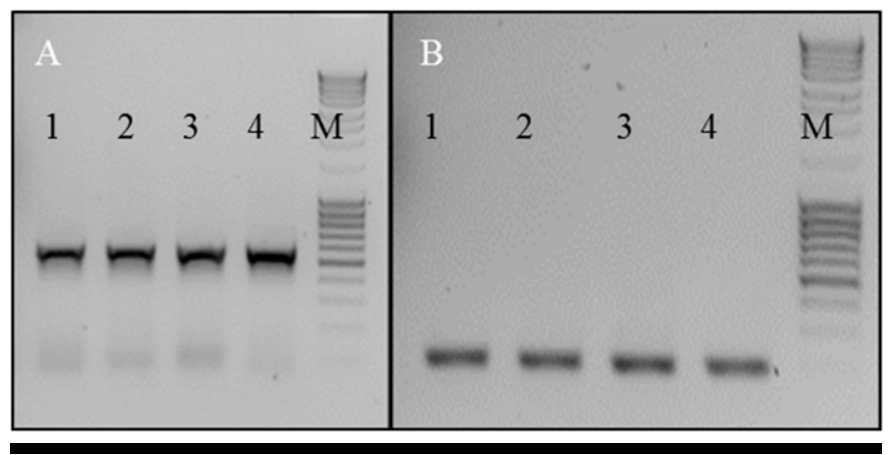

\section{FIGURE 2}

(A) PCR amplification products to detect Xanthomonas citri pv. citri in canker lesions from Mexican lime using Xac01/Xac02 primers ( $580 \mathrm{bp}$ ) (Coletta-Filho et al. 2006) and (B) J-pth1/J-pth2 primers ( 200 bp) (Cubero and Graham 2002). Lanes: 1 to 4, PCR amplicons derived from four separate DNA extracts isolated from the canker lesions; M, $1 \mathrm{~kb}$ plus DNA (Thermo Fisher Scientific) ladder.

\begin{tabular}{|c|c|c|c|}
\hline \multicolumn{4}{|c|}{$\begin{array}{l}\text { TABLE } 1 \\
\text { Leaf inoculations of different citrus cultivars with sap extracts from ground-up canker lesions collected } \\
\text { from Mexican lime leaves affected by Xanthomonas citri subsp. citri }\end{array}$} \\
\hline Common name & Scientific name & Symptoms & Note \\
\hline Mexican lime ${ }^{a}$ & Citrus aurantiifolia & + & Classic symptoms \\
\hline Mexican lime (thornless) ${ }^{\mathrm{a}}$ & Citrus aurantiifolia & + & Classic symptoms appear few days after thorny lime \\
\hline Persian lime $^{\mathrm{a}}$ & Citrus latifolia & $(+?)$ & $\begin{array}{l}\text { Center of inoculation site falls out; some tiny raised } \\
\text { lesions on the edge }\end{array}$ \\
\hline Clementine mandarin ${ }^{\mathrm{a}}$ & $\begin{array}{l}\text { Citrus } \times \text { reticulata }= \\
\text { C. } \text { clementina }\end{array}$ & $(+?)$ & Tiny raised lesions at edge \\
\hline Rio Red grapefruit ${ }^{\mathrm{a}}$ & Citrus $\times$ paradisi & - & \\
\hline Eureka lemon (variegated) ${ }^{\mathrm{a}}$ & Citrus limon & $(+?)$ & 2 leaves with rings of tiny spots \\
\hline $\begin{array}{l}\text { Sweet orange (navel, Marrs, Pineapple, } \\
\text { Valencia) }^{\mathrm{a}}\end{array}$ & Citrus sinensis & - & $\ldots$ \\
\hline Ponderosa lemon ${ }^{c}$ & Citrus limon $\times$ C. medica & - & $\ldots$ \\
\hline Palestine sweet lime ${ }^{c}$ & Citrus limettoides & - & $\ldots$ \\
\hline Pomona sweet lemon ${ }^{\mathrm{c}}$ & Citrus limon & - & $\ldots$ \\
\hline Citron $^{\mathrm{c}}$ & Citrus medica & - & $\ldots$ \\
\hline
\end{tabular}

${ }^{\text {a }}$ Grafted potted plants.

${ }^{\mathrm{b}}$ Seedling.

${ }^{\mathrm{c}}$ Detached twigs (used because potted trees not available). 


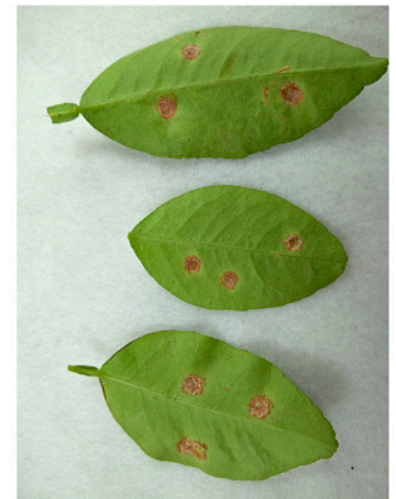

A

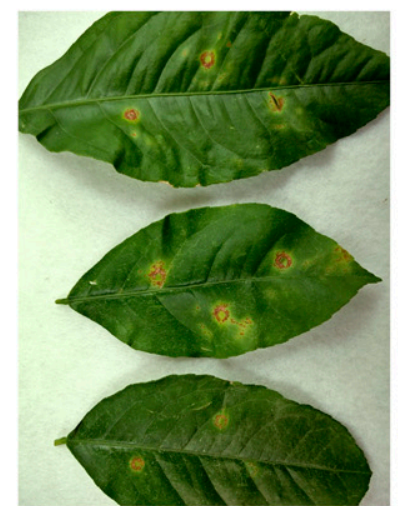

D

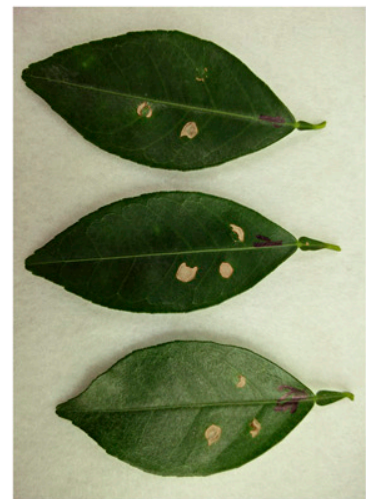

$\mathbf{H}$

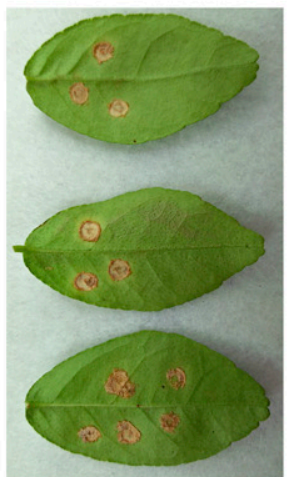

B

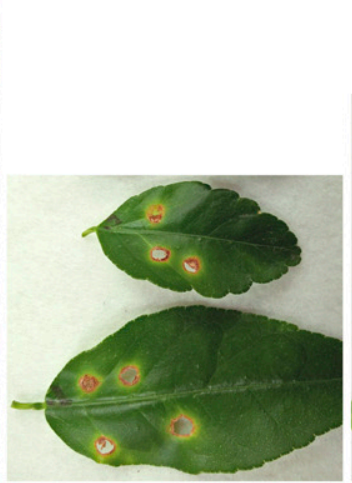

E

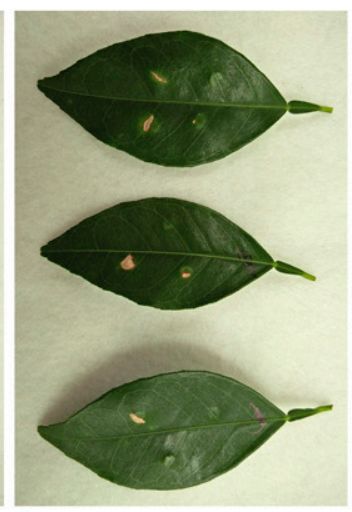

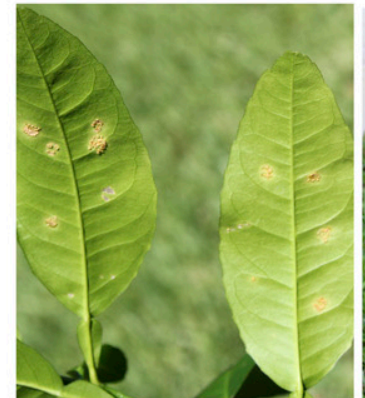

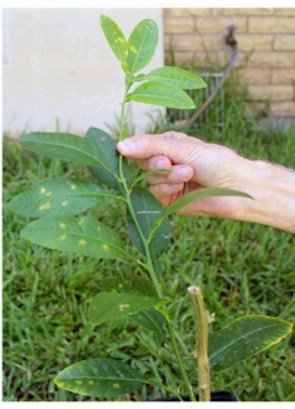

C

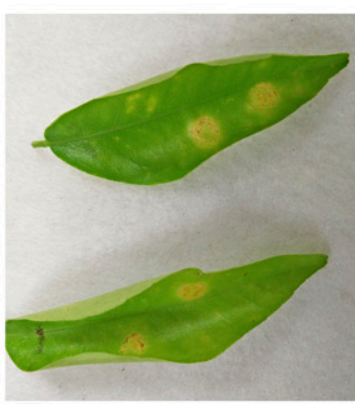

$\mathbf{F}$

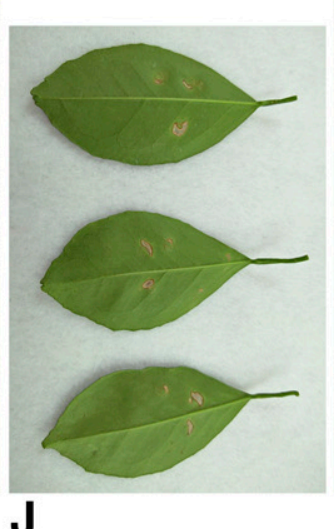

G
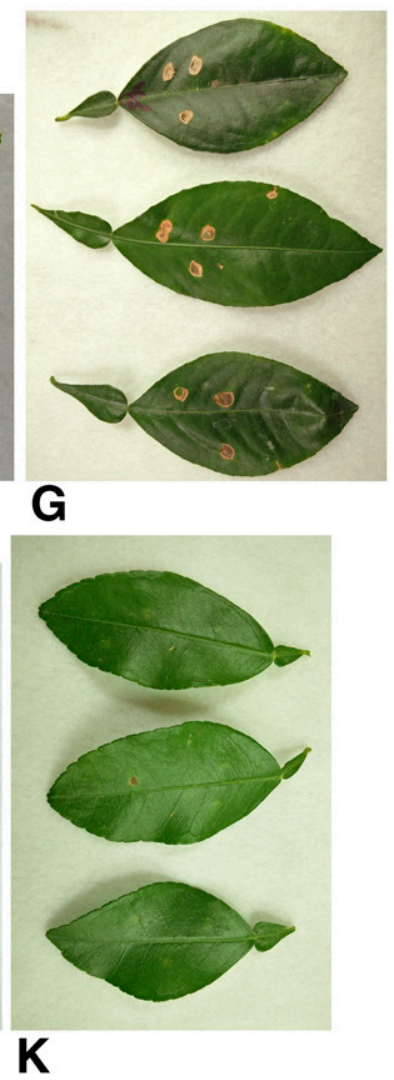

\section{FIGURE 3}

Results of artificial inoculations of different citrus cultivars and species with extracts from citrus canker lesions from Mexican lime in Rancho Viejo, TX (see Table 1): (A) Mexican lime; (B) Thornless Mexican lime; (C) Alemo; (D) Persian lime; (E) Meyer lemon; (F) Clementine; (G) Sour orange; (H) Marrs; (I) Navel; (J) Valencia; and (K) Rio Red.

25.5, 28.8, 27.1, 30.8, 29.9, and 29.45 in two separate reactions. The cPCR with primer set Xac01/Xac02 produced a 580-bp amplicon (Fig. 2A). In addition, primer set J-pth $1 / 2$ amplified a $\sim 200$-bp amplicon in all three canker-positive DNA samples (Fig. 2B). On the other hand, the primers of Hartung et al. 1993 (4 forward and 3 reverse primers; 11 different primer combinations) showed negative results (data not shown). The nucleotide sequence of J-pth1/2 amplicon showed $100 \%$ identities to $p$ thA sequences of several NCBI accessions of $X$. citri subsp. citri (e.g., CP004400, U28802, AB021365). Tests using ImmunoStrip (Agdia) for the $X$. citri subsp. citri A strain in sap extracts of infected lime leaves were negative.

Artificial inoculations. Leaf inoculations by infiltration with the sap of ground-up canker leaf lesions produced typical canker symptoms on both thorny and thornless Mexican lime leaves 7 dpi (Table 1, Fig. 3).
Persian lime, Meyer lemon, Clementine mandarin, and Eureka lemon leaves showed slightly raised tiny lesions at the edge of inoculation sites (Fig. 3). On the remaining citrus species, only water-soaked areas becoming chlorotic at the inoculation site were observed; however, they did not show any typical canker lesions even after 21 dpi, whereas Mexican lime leaves showed typical erumpent, callus-like, raised lesions by 21 dpi (Table 1).

Isolation and cultures. Yellow, convex, and mucoid colonies typical of $X$. citri subsp. citri were isolated on DIFCO NA (Becton, Dickinson and Co., Sparks MD) from several field leaf samples from Texas. Successive restreaking of individual colonies on NA resulted in pure cultures being obtained. The colonies were uniform in appearance and of confirmed purity. Real-time PCR of individual colonies confirmed their identity. 


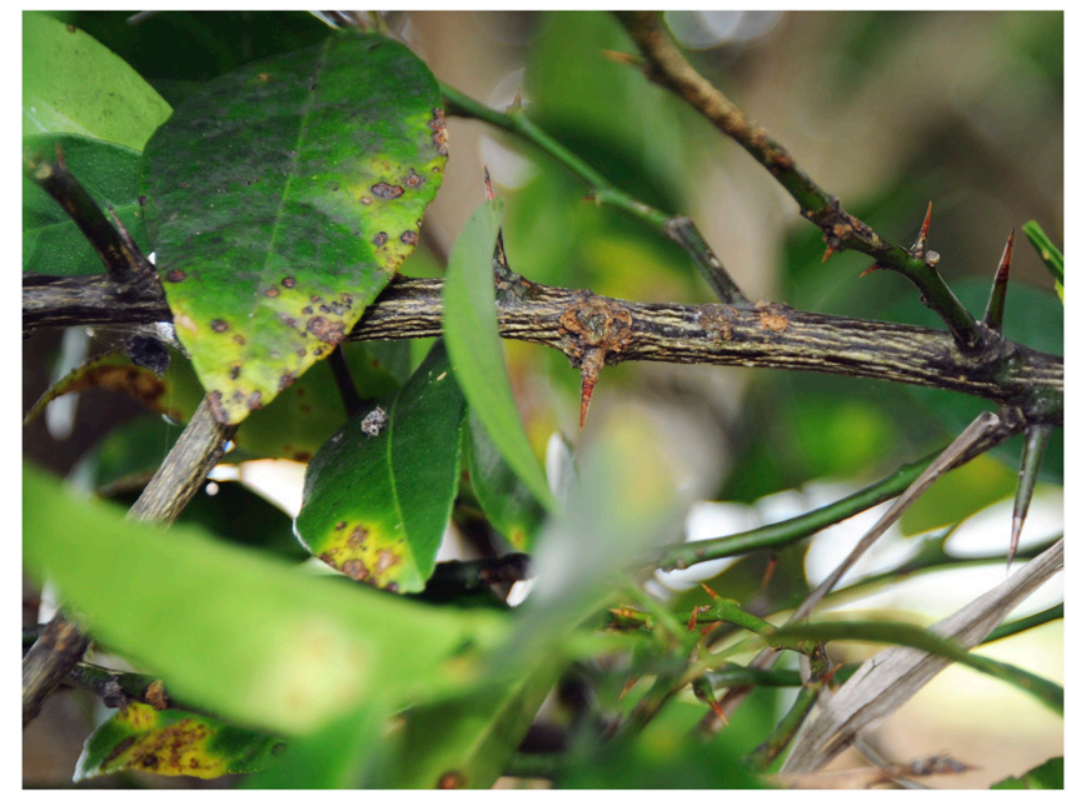

FIGURE 4

Example of stem lesions found on Mexican lime trees surveyed to determine the age and epicenter of the infection (photo courtesy David Bartels).

Estimating the age of infection. A total of 130 citrus trees from 59 residential properties were examined to estimate the age of the citrus canker infection. A total of 79 Mexican lime and one makrut lime were examined and all of these trees had canker symptoms (Fig. 1). The other citrus varieties surveyed included grapefruit, lemon, sweet orange, sour orange, tangerine, and kumquat; all of which had no canker symptoms.

Citrus canker stem lesions were found on 36 of the 80 total lime trees. The median branch diameter with a lesion was $5 \mathrm{~mm}$ with a range of $1.5 \mathrm{~mm}$ to $77 \mathrm{~mm}$ (Figs. 4 and 5). There was a total of 12 Mexican lime trees with lesions on branch diameters of $13 \mathrm{~mm}$ or greater on seven different properties. All of these trees were within $4.2 \mathrm{~km}(2.6$ miles) of each other. Eleven of the 12 trees were within $1.8 \mathrm{~km}(1.1$ miles) of each other within the town of Rancho Viejo (Fig. 5). All trees were within $120 \mathrm{~m}$ of open water along a resaca that runs through the town or an irrigation canal and drainage ditch, which would allow for much more humid conditions throughout the year (Fig. 5).

Estimates of the age of the canker lesions were based on the approximate flushing cycles and branch diameters. We were not able to cut the branches at the time of the survey to use more accurate dendrochronology techniques involving growth rings within the branch. There is also a difficulty in estimating the number of flushing cycles per year as all of the trees surveyed were residential trees with unknown quality of horticultural care. The largest branch with a lesion was $77 \mathrm{~mm}$, which we estimated to be approximately 5 to 6 years old. In the same area, another tree heavily infected with canker had a larger trunk that was cut away and allowed to regrow from the base. This tree may have been one of the earliest infected, but many of the trees had been removed long before we started the aging survey using stem lesions.

Delimiting survey and tree removal. A total of 50 citrus orchards (224 acres) within a 5-mile radius around citrus canker-positive sites were surveyed. All of them were negative for citrus canker. In addition, 210 acres of commercial citrus orchards within a 2-mile radius around the current quarantine area were surveyed and none of the trees showed citrus canker symptoms; therefore, no samples were collected. Surveys of all residential properties within the quarantine area continued up to the present. In total, 197 positive samples were collected from 185 properties and confirmed for canker by USDA-APHIS (Fig. 6). In addition, a further 59 symptomatic trees were found. All 256 infected trees were removed. The total number of residential properties surveyed was 3,579. All of the commercial grapefruit and sweet orange orchards surveyed were negative for citrus canker.

\section{Discussion and Current Situation of Citrus Canker in Texas}

The canker eradication program in Texas described by Dopson (1964) was clearly successful, since subsequent surveys failed to detect the disease for over 70 years (Skaria and da Graça 2012). Recent surveys conducted by the USDA-APHIS-CPHST Mission Laboratory since 2006 using the Mexican fruit fly trap trees as sentinel trees did not detect citrus canker on grapefruit or orange in residential properties or groves (Salas and Parker 2008). Unfortunately, Mexican lime was not the primary target on these surveys and Brownsville was not heavily surveyed. Citrus canker is primarily spread by wind-driven rain. The climate of South Texas is drier than that of Florida, where the disease is now endemic (Gottwald et al. 2002a). The average rainfall in Florida ranges from 50 inches $(1,270 \mathrm{~mm})$ per year in Orlando to nearly 62 inches $(1,574.8 \mathrm{~mm})$ in Miami (www.usclimatedata.com), whereas in the LRGV it ranges from 22 inches $(558.8 \mathrm{~mm}$ ) per year in McAllen-Mission to 27 inches $(685.8 \mathrm{~mm})$ in Brownsville, with frequent extended rain-free periods. The conditions in South Texas are therefore not normally conducive to outbreaks of citrus canker. The discovery of canker in 2015 occurred toward the end of a year of an unusually high amount of rainfall, with Brownsville, located 12 miles from Rancho Viejo, receiving nearly 47 inches (1,193.8 mm), 13.68 inches of which fell in the month of October when the first infected tree was found.

The $\mathrm{A}^{\mathrm{W}}$ strain of $X$. citri pv. citri has previously only been reported from one county in Florida (Sun et al. 2004). The oldest stem lesions found in this study were estimated to be 4 to 6 years old and were clustered in close proximity, suggesting that this may be where the first infected tree was located and that the pathogen remained nearby until the unusually wet weather of 2015 , its wind and rain 


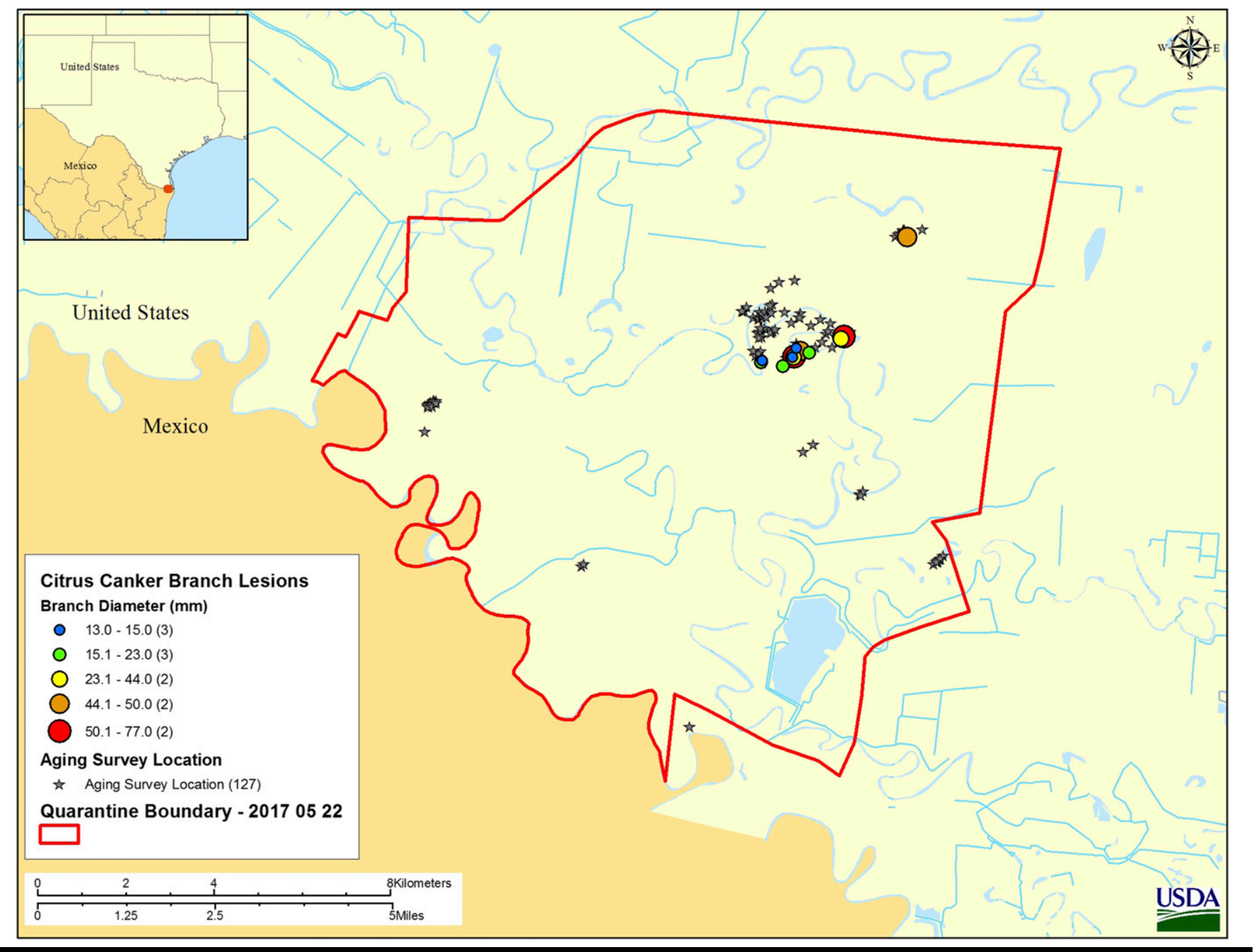

FIGURE 5

Citrus canker aging survey within the Rancho Viejo, TX, quarantine area, based on branch diameter at the lesions site and approximate flushing cycles. All data presented were randomly distributed (jittered) within a set distance to preserve confidentiality and prevent reidentification of specific locations.

spreading the disease to other trees and perhaps enhanced by shared ground-keeping activities observed there. In April 2016, Mexican lime trees in residential sites across the border in Matamoros, Mexico, were found to be infected with the same strain of bacteria; 423 were detected and removed (Pedro Robles, D. G. Sanidad Vegetal, personal communication, 2017).

Although the $\mathrm{A}^{\mathrm{W}}$ strain has a limited host range, it is highly infectious. We observed in the host-range study that infection was readily spread from the inoculated, fully expanded C. macrophylla leaves to the uninoculated upper leaves, possibly due to a rainfall event 1 week after inoculation. Mexican limes are common in residential properties in the LRGV, especially in Brownsville where winter temperatures are slightly warmer than in other locations; there is also one commercial lime orchard in the region. The main commercial varieties of citrus grown in the LRGV are grapefruit and oranges, which were shown not to be hosts in this study.

This outbreak does clearly show how readily exotic pathogens can become established in a new area even though moving citrus plants and equipment used in the production areas from quarantined areas is illegal. Despite the fact that environmental conditions in the LRGV are not normally conducive to canker, the pathogen can survive at a low level, avoiding detection. The unusually wet season of 2015 might have caused the spread of the disease.

Removal and destruction of infected trees has previously eradicated the A strain form Texas. Thus, efforts in surveying and eliminating infected trees may eradicate the $\mathrm{A}^{\mathrm{W}}$ strain. Although there is no evidence that $\mathrm{A}^{\mathrm{W}}$ could mutate and infect other citrus varieties, this risk needs to be eliminated.

The recent discovery of canker-infected trees of different citrus varieties in Houston and Richmond TX areas (https://texasagriculture.gov/ RegulatoryPrograms/PlantQuality/PestandDiseaseAlerts/CitrusCanker. aspx) has raised the alert level in Texas since this strain appears to be the Asian (A) strain. USDA APHIS PPQ is leading a survey and an eradication program in the affected areas is in place.

\section{Acknowledgments}

Funding for this program was provided by USDA APHIS PPQ (Agreement \# 15-8448-1520 CA). We would like to thank Drs. Tim Gottwald and Jim Graham for providing information and directions on estimating the age of the infection. We would also like to thank Jason Carlson, Cynthia Garcia, and Oscar Pizano for their assistance in conducting the aging survey. 


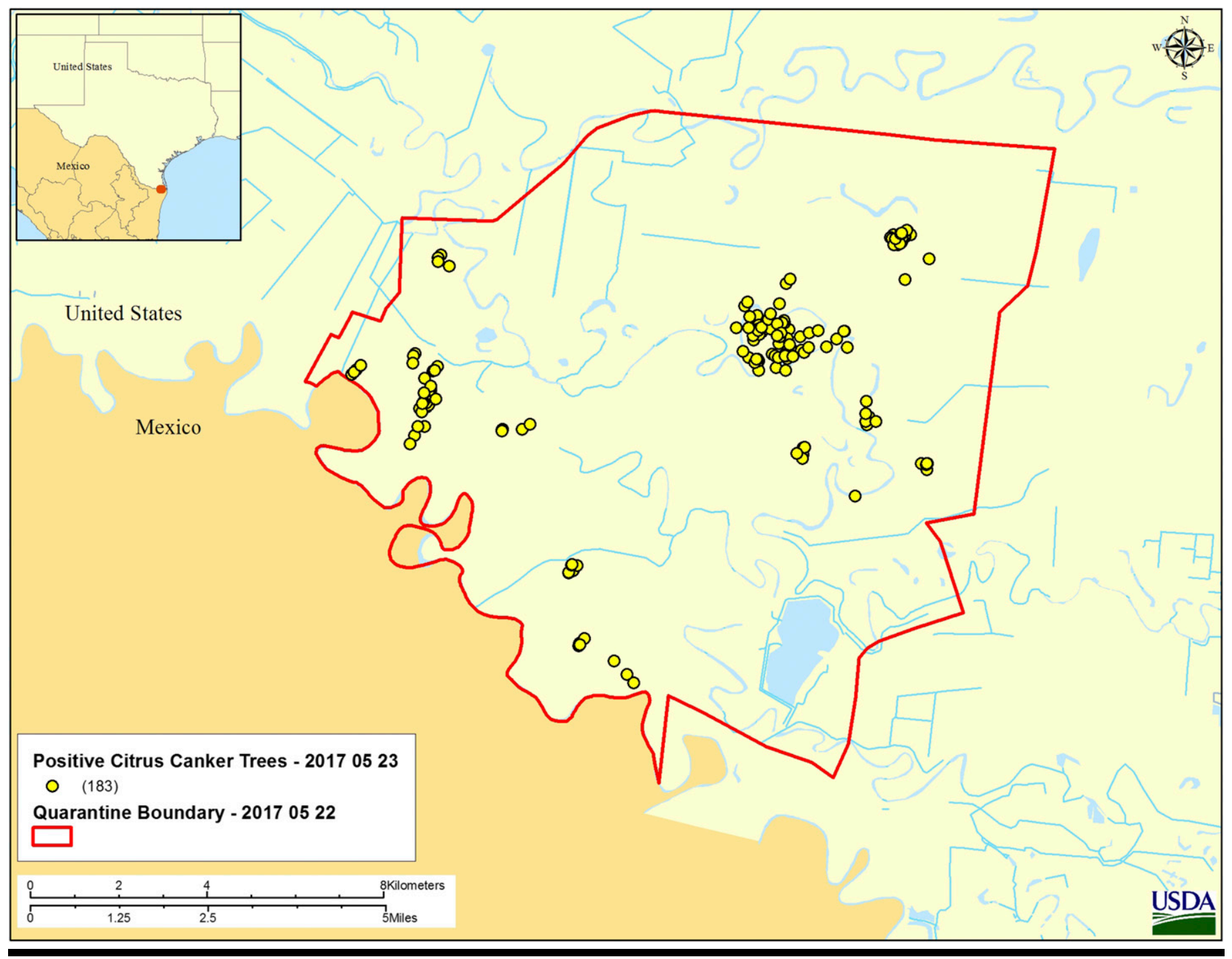

FIGURE 6

Locations of citrus canker positive trees in the Rancho Viejo, TX, quarantine zone. All data presented were randomly distributed (jittered) within a set distance to preserve confidentiality and prevent reidentification of specific locations.

\section{Literature Cited}

Berger, E. W. 1914. Citrus canker in the Gulf Coast country, with notes on the extent of citrus culture in the localities visited. Proc. Fla. State Hortic. Soc. 27: 120-127.

Coletta-Filho, H. D., Takita, M. A., de Souza, A. A., Neto, J. R., Destéfano, S. A. L., Hartung, J. S., and Machado, M. A. 2006. Primers based on the $r p f$ gene region provide improved detection of Xanthomonas axonopodis pv. citri in naturally and artificially infected citrus plants. J. Appl. Microbiol. 100:279-285.

Cubero, J., and Graham, J. H. 2002. Genetic relationship among worldwide strains of Xanthomonas causing canker in citrus species and design of new primers. Appl. Environ. Microbiol. 68:1257-1264.

Derso, E., and Sijam, K. 2007. Citrus canker: A new disease of Mexican lime (Citrus aurantifolia) and sour orange (C. aurantium) in Ethiopia. Fruits 62:89-98.

Dopson, R. N. 1964. The eradication of citrus canker. Plant Dis. Reptr. 48:30-31.

Francis, M. I., Peña, A., and Graham, J. H. 2010. Detached leaf inoculation of germplasm for rapid screening of resistance to citrus canker and citrus bacterial spot. Eur. J. Plant Pathol. 127:571-578.

Gottwald, T. R., Graham, J. H., and Egel, D. S. 1992. Analysis of foci of Asiatic citrus canker in a Florida citrus orchard. Plant Dis. 76:389-396.

Gottwald, T. R., Graham, J. H., and Schubert, T. S. 1997. An epidemiological analysis of the spread of citrus canker in urban Miami, Florida, and synergistic interaction with the Asian citrus leafminer. Fruits 52:371-378.
Gottwald, T. R., Graham, J. H., and Schubert, T. S. 2002a. Citrus canker: The pathogen and its impact. Plant Health Prog. doi:10.1094/PHP-2002-0812-01-RV.

Gottwald, T. R., Sun, X., Riley, T., Graham, J. H., Ferrandino, F., and Taylor, E. L. 2002b. Georeferenced spatiotemporal analysis of the urban citrus canker epidemic in Florida. Phytopathology 92:361-377.

Graham, J. H., Gottwald, T. R., Cubero, J., and Achor, D. S. 2004. Xanthomonas axonopodis pv. citri: factors affecting successful eradication of citrus canker. Mol. Plant Pathol. 5:1-15.

Hartung, J. S., Daniel, J. F., and Pruvost, O. P. 1993. Detection of Xanthomonas campestris pv. citri by the polymerase chain reaction. Appl. Environ. Microbiol. 59:1143-1148.

Irey, M., Gottwald, T. R., Graham, J. H., Riley, T. D., and Carlton, G. 2006. Posthurricane analysis of citrus canker spread and progress towards the development of a predictive model to estimate disease spread due to catastrophic weather events. Plant Health Prog. doi:10.1094/PHP-2006-0822-01-RS

Mavrodieva, V., Levy, L., and Gabriel, D. W. 2004. Improved sampling methods for real-time polymerase chain reaction diagnosis of citrus canker from field samples. Phytopathology 94:61-68.

Pruvost, O., Roumagnac, P., Gaube, C., Chiroleu, F., and Gagnevin, L. 2005. New media for the semiselective isolation and enumeration of Xanthomonas campestris pv. mangiferaeindicae, the causal agent of mango bacterial black spot. J. Appl. Microbiol. 99:803-815.

Salas, B., and Parker, P. 2008. Survey of huanglongbing (HLB) and citrus canker in the Rio Grande Valley. (Abstr.) Phytopathology 98:S138. 
Singh, R., Hardy, T. N., and Spitzer, W. E. 2014. Citrus canker: Another hurricane for Louisiana's citrus industry. (Abstr.) Phytopathology 104: S2.9.

Skaria, M., and da Graça, J. V. 2012. History lessons towards proactive citrus canker efforts in Texas. Subtrop. Plant Sci. 64:29-33

Stall, R. E., and Civerolo, E. L. 1991. Research relating to the recent outbreak of citrus canker in Florida. Annu. Rev. Phytopathol. 29:399-420.

Stevens, H. E. 1914. Citrus canker. Fla. Agric. Exp. Station Bull. 122:111-118.
Sun, X., Stall, R. E., Jones, J. B., Cubero, J., Gottwald, T. R., Graham, J. H., Dixon, W. N., and Schubert, T. 2004. Detection and characterization of a new strain of citrus canker bacteria from Key/Mexican line and alemow in South Florida. Plant Dis. 88:1179-1188.

Vernière, C., Hartung, J. S., Pruvost, O. P., Civerolo, E. L., Alvarez, A. L., Maestri, P., and Luisetti, J. 1998. Characterization of phenotypically distinct strains of Xanthomonas axonopodis pv. citri from Southwest Asia. Eur. J. Plant Pathol. 104:477-487. 